\title{
Dopad technického zasněžování na toky v Krkonoších
}

\section{PAVEL TREML}

Klíčová slova: technické zasněžování - sjezdovka - průtok - hladina toku minimální zůstatkový průtok - sníh - znečištění toků - ochrana př́rody

\section{SOUHRN}

Přispěvek se zabývá dopadem technického zasněžování na vybrané toky na území Krkonoš z pohledu změn v průtocích, z hlediska interakce možného znečištění prírodního prostředí z toků a opačně, a rozdílů mezi prírodním sněhem a sněhem ležícím na sjezdovce z hlediska hustoty sněhu a s tím souvisejícím odlišným odtokovým vlastnostem.

\section{ÚVOD}

Následující příspěvek analyzuje dopad technického zasněžování na vybrané toky $v$ Krkonoších z pohledu změn v průtocích, z hlediska interakce možného znečištění prírodního prostředí z toků a opačně a rozdílů mezi prírodním sněhem a sněhem ležícím na sjezdovce z hlediska hustoty sněhu a souvisejících odlišných odtokových vlastností.

Problematika hodnocení dopadu odběrů vody pro technické zasněžování na průtoky vodních toků nebyla prozatím na území České republiky komplexně řešena. Pokud byla tematika řešena, tak pouze z hlediska vlivu na konkrétní profil (z něhož by se měla voda pro technické zasněžování odebírat) v rámci povolovacího rízení. Pro každý z těchto odběrných profilů je vodoprávním úřadem vydáno povolení pro nakládání s vodou. Povolení od vodoprávního úřadu obsahuje mj. údaje o velikosti minimálního zůstatkového průtoku, maximálního povoleného denního odběru vody, maximálního povoleného měsíčního odběru vody a maximálního povoleného ročního odběru vody. Těmito limity by se měli jednotliví odběratelé rídit.

Podrobnější analýza porovnání kumulativního vlivu více odběrů na jednotlivých povodích nebyla známa. V roce 2009 byla na základě požadavku Správy KRNAP zpracována pilotní studie o vlivu technického zasněžování na průtoky dílčích povodí Labe, Úpy a Jizery vzhledem k teoretickým závěrovým profilům v místech odtoku těchto tří toků z území Krkonošského národního parku a jeho ochranného pásma [1]. Byl počítán maximální kumulativní vliv ze všech povolených odběrů vody pro technické zasněžování. Za běžných podmínek nebyl shledán podstatný vliv.

První pravidelná terénní měření, z nichž by se dal vypozorovat vliv odběrů vody pro technické zasněžování na vodní toky, byla zahájena v zimě 2011/2012 na Zeleném a Vlčím potoce $v$ Peci pod Sněžkou pod odběrnými profily pro technické zasněžování. Na těchto profilech byl vliv technického zasněžování na prưtoky patrný. Jednalo se ale pouze o dvě bodová měření v antropogenně ovlivněném prostředí s více vlivy, na základě nichž nebylo možno objektivně zobecnit získané poznatky.
Proto byl inicializován vznik komplexnějšího projektu, který by se problematikou zabýval. Technologickou agenturou ČR bylo v projektu Epsilon podpořeno řešení projektu s názvem Podpora dlouhodobého plánování v oblasti vodního hospodářství na území Krkonošského národního parku s důrazem na řešení problematiky vlivu technického zasněžování na pokles průtoků s cílem zvýšit dlouhodobou efektivitu ochrany prírody a krajiny (označení TH02030080). Projekt se zabývá problematikou vlivu dopadů technického zasněžování na vodní toky velmi komplexně - od vytvoření měřicí sítě pro sledování dopadů technického zasněžování na vodní toky na 22 profilech na území Krkonoš, pres komplexní zhodnocení vlivu technického zasněžování na změnu průtoků v tocích, srovnání těchto dopadů s ostatními vlivy, návrh opatření na eliminaci negativních dopadi̊, včetně vytvoření metodiky pro povolování odběrů vody pro technické zasněžování, tak aby tyto odběry vody byly spravedlivé ke všem odběratelům a bylo zajištěno trvale udržitelné hospodaření s vodou, které zajistí odběry vody pro všechny potenciální odběratele a zároveň nebude narušena ekologická rovnováha $v$ toku. Měla by být vytvořena i mapa ovlivnění území Krkonoš technickým zasněžováním a jinými odběry. Kromě samotného pozorování dopadů v terénu probíhá i matematické modelování dopadů. Výsledky tohoto projektu by měly díky nezávislým měřením ukázat, zda skutečně odběry vody pro technické zasněžování přispívají významně ke snížení hladiny v tocích, nebo naopak zda se jedná hlavně o nepodložené domněnky odpůrců technického zasněžování.

Následující príspěvek představí vybrané části z počáteční fáze probíhajícího výzkumu. V úvodu bude ukázán na výsledcích pozorování možný dopad vlivu odběrů vody pro technické zasněžování na změnu průtoků. Následně je prezentován doplňkový výzkum možné vzájemné interakce odběru vody ze znečištěného toku a prrírodního prostředí či rozdíly mezi směsí technického a príirodního sněhu na sjezdovce a prírodního sněhu mimo sjezdovku.

Literatura zabývající se problematikou technického zasněžování a tematikou sněhu se věnuje zejména dopadům klimatickým změn na možnosti technického zasněžování [např. 1-6]. Další skupinu tvoří studie zachycující ekonomický př́nos lyžování pro daný region [např. 3, 7, 8]. Velké množství studií zkoumá dopady technického zasněžování na ekosystémy (rostliny a živočichy) [podrobná rešerše v 9, dále např. 10-12], světelné znečištění [13], popř. Ize nalézt úkoly snažící se nějakým způsobem spočítat neznámé množství vody použivané pro technické zasněžování [např. 1, 2, 4, 14-16]. Do další skupiny projektů je možno zařadit úkoly související s výzkumem sněhu - jeho vlastnostem, hydrologickému režimu, modelováním výšky sněhové pokrývky, lavinám apod. [např. 17-22]. Zvláštní skupinu tvoří souhrnné studie ekologických organizací poukazující na negativní dopady technického zasněžování [23, 24]. 


\section{VYBRANÉ LOKALITY, METODIKA MĚŘENÍ PRU゚TOKŮ}

Na území Krkonošského národního parku a jeho ochranného pásma se odebírá voda pro technické zasněžování celkem na 48 místech. Pro studium dopadů vlivu technického zasněžování na změnu průtoků byly vybrány profily, které leží na menších a středně velkých tocích (do mediánu průtoku 0,2 $\mathrm{m}^{3} / \mathrm{s}$ ), protéká $v$ nich voda po celý rok a je možno měřit průtoky nad i pod profilem, z něhož se odebírá voda pro technické zasněžování. Na základě těchto kritérií bylo vybráno 22 pozorovacích profilů (obr. 1). Profily se nacházejí na celém území Krkonoš v různých fyzicko-geografických podmínkách. Porovnávány jsou i dopady ostatních antropogenních činností.

Pro prezentaci v tomto príspěvku byla vybrána data ze 14 hlavních profilů, z nichž jsou k dispozici spolehlivá data. Jsou na nich instalovány hladinoměry od firmy Fiedler s online přenosem dat a měřením výšek hladin po 5 minutách. Vyhodnocena data jsou z období mezi 1. prosincem 2017 a 23. dubnem 2019. Pro jednoznačné označení profilů v dalším textu je užit název toku a pořadové číslo profilu v pořadí od pramene (např. pozorovací profil na Svatopetrském potoce ve Špindlerové Mlýně umístěný nad odběrem vody u sjezdovky Stoh má označení Svatopetrský 1).

Měření průtoků probíhá průběžně během celého roku při různých vodních stavech. Na základě měrné křivky využívající závislosti získaných bodových hodnot z křivky kontinuálně sledované výšky hladiny toku a naměřenými průtoky $\checkmark$ rámci terénních měření byly odvozeny kontinuální hodnoty průtoků, jež byly dále analyzovány. Měrné křivky závislosti naměřených průtoků a výšky hladin toku jsou průběžně zpresňovány. Díky tomu může docházet u hodnot kontinuálně odvozených průtoků v čase k mírným změnám (drobnému posunu hodnot odvozených průtoků). $V$ prípadě, že se hodnoty průtoků v tocích u odvozených křivek průtoků pohybují těsně kolem hodnoty minimálního zůstatkového průtoku a probíhá odběr vody, nelze s ohledem na tuto možnou nepřesnost objektivně posoudit, zda byl odběr vody v souladu s vydaným povolením, či zda eventuálně mohl být překročen povolený limit pro odběr vody.

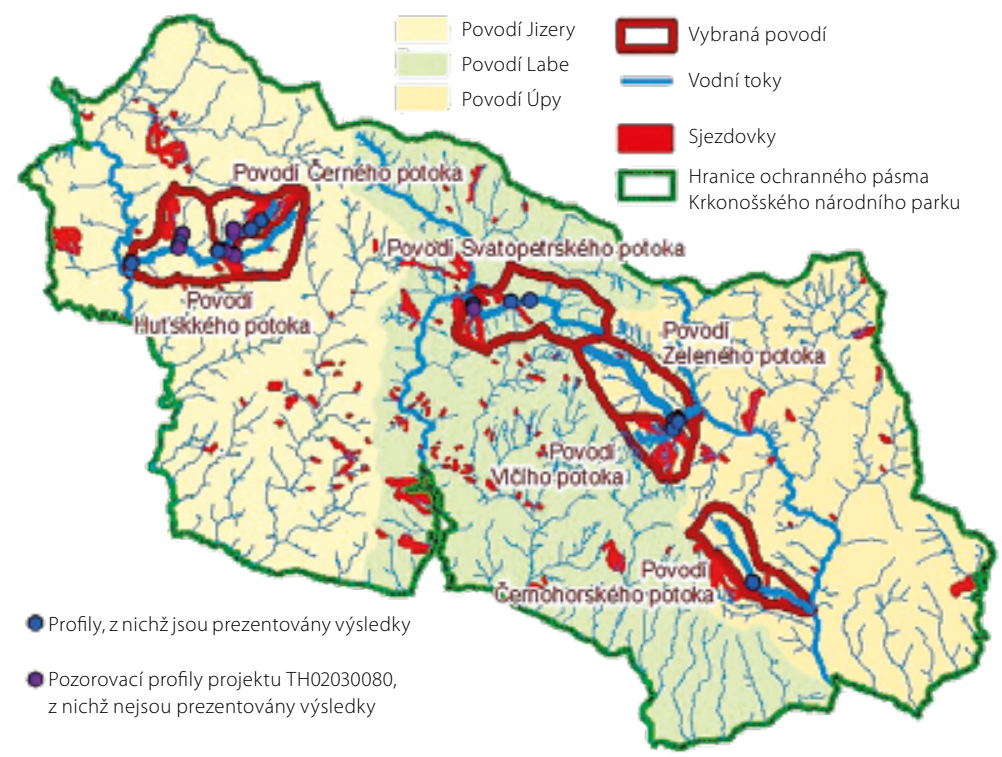

Obr. 1. Vybraná povodí pro sledování dopadů technického zasněžování Fig. 1. Selected river basins for monitoring the impact of snowmaking

\section{DOPAD TECHNICKÉHO ZASNĚŽOVÁNÍ NA ZMĚNU PRŮTOKŮ}

\section{Dopad na experimentální povodí}

Měření na tocích byla zahájena v říjnu a listopadu 2017. Díky tomu jsou k dispozici data ze dvou zimních období - zimy 2017/2018, zimy 2018/2019 a léta 2018. Zima 2017/2018 byla běžnou zimou posledních let s ideálními podmínkami pro výzkum dopadů technického zasněžování na pokles průtoků - nebylo př́liš teplo ani príliš zima. Jediným obdobím, kdy zamrzaly toky v Krkonoších, byl přelom února a března 2018. Následovaly suché léto a podzim, kdy byly zaznamenány na tocích $v$ Krkonoších extrémně nízké průtoky, přičemž nízké průtoky (pod hranicí $Q_{330 d}$ ) přetrvávaly v Krkonoších do přelomu listopadu a prosince 2018. S ohledem na tuto skutečnost nebylo možno na řadě toků technicky zasněžovat. V prosinci došlo ke zlepšení - začalo sněžit. Díky oteplení sníh tál a došlo ke zvýšení průtoků, nicméně v porovnání se zimou 2017/2018 byly průtoky v krkonošských tocích menší. Na začátku ledna 2019 se situace obrátila a nasněžilo velké množství prírodního sněhu - např. na Labské Boudě bylo k 15. lednu $220 \mathrm{~cm}$ sněhu, na Sněžce $210 \mathrm{~cm}$ a v Peci pod Sněžkou $103 \mathrm{~cm}$ prírodního sněhu [25]. Díky dostatku prírodního sněhu nebylo potřeba sjezdovky technicky zasněžovat.

V extrémních prípadech je odebíráno z vodního toku až 70 \% objemu protékající vody. Zda se jedná o velké objemy vody, které mohou ohrozit vodní tok, či nikoliv, je potřeba hodnotit u každého toku zvlášt podle jeho hydrologických poměrů a výšky hladiny zůstatkového objemu. Jiná situace nastává, pokud se aktuální velikost průtoku bliží k hranici minimálního zůstatkového průtoku, jiná pokud překračuje hranici povodňových stupňů. V př́padě odběrů vody v období minimálních průtoků je jakýkoliv odběr vody nežádoucí a může významně poškodit ekosystém toku, naopak při odběrech vody během povodňových stavů se může docílit zmírnění negativního vlivu rozlivu povodňové vody.

Ke správnému zhodnocení dopadu vlivu technického zasněžování na průtoky $v$ tocích je zapotřebí znát jejich roční průběh a situaci, za níž se voda odebírá. Krkonošské toky mají největší průtoky bud' na jaře nebo v zimě a nejnižší na podzim nebo v létě (obr. 2). Z pohledu hodnocení vlivu dopadu je proto ideální porovnat zimní průtoky i s průtoky v letním období.

V případě běžné zimy (jako byla zima 2017/2018), kdy se střídají chladnější období s oblevami a dlouhodobě nemrzne, mají toky dostatek vody. Ve většině prípadů i v době technického zasněžování protéká korytem toku více vody než v letním a podzimním období. Je to dobře patrné z podrobné analýzy variability denních hodnot průtoků během roku a srovnání průtoků v období, kdy se typicky může zasněžovat (měsíce prosinec až únor) a období, kdy se nezasněžuje, resp. byly $v$ roce 2018 naměřeny nejmenší průtoky (měsíce červen až zárí). Na polovině profilů (8 ze 14 - profily Černý 1, Černohorský 1, Vlčí 2, príitok Hut’ského potoka, Hut'ský 6 a na všech profilech na Svatopetrském potoce) byla zimní minima vyšší než medián průtoků v letním období, přičemž přítok Hut'ského potoka, z něhož se i zasněžuje, je potok, který má ze sledovaných toků nejmenší roční medián průtoku. Obdobně se odebírá voda pro technické zasněžování i z Vlčího potoka a Svatopetrského potoka. Na ostatních profilech byly mediány letních průtoků vy̌̌ší než zimní minimum, avšak vždy nižší než hodnota $Q_{330 d}$ pro letní období.

Na začátku zimy 2018/2019 (měsíce listopad a prosinec) vrcholilo hydrologické sucho z předchozího období. Z tohoto důvodu byly měřeny na sledovaných tocích nízké průtoky, při kterých nebylo vhodné odebírat vodu z toků (nejen pro účely technického zasněžování). Byly zaznamenány odběry vody ze Zeleného, Vlčího, Černohorského a Svatopetrského potoka. Naopak na Černém potoce nebyly zaregistrovány žádné odběry. 


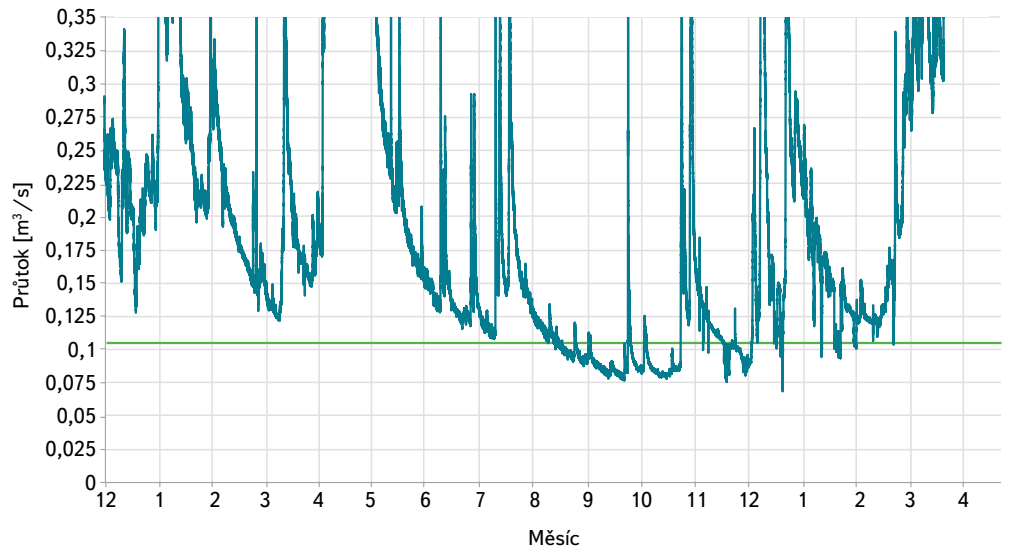

Obr. 2. Průběh průtoků od prosince 2017 do dubna 2019 na Svatopetrském potoce pod odběrem vody pro technické zasněžování ve Svatém Petru ve Špindlerově Mlýně (s ohledem na zachycení vývoje průběhu nejmenších hodnot v grafu zobrazeny pouze hodnoty průtoků nižší než $0,35 \mathrm{~m}^{3} / \mathrm{s}$ )

Fig. 2. Running of discharges during the year at the Svatopetrský stream under water abstraction for snowmaking in Svatý Petr in Špindlerův Mlýn

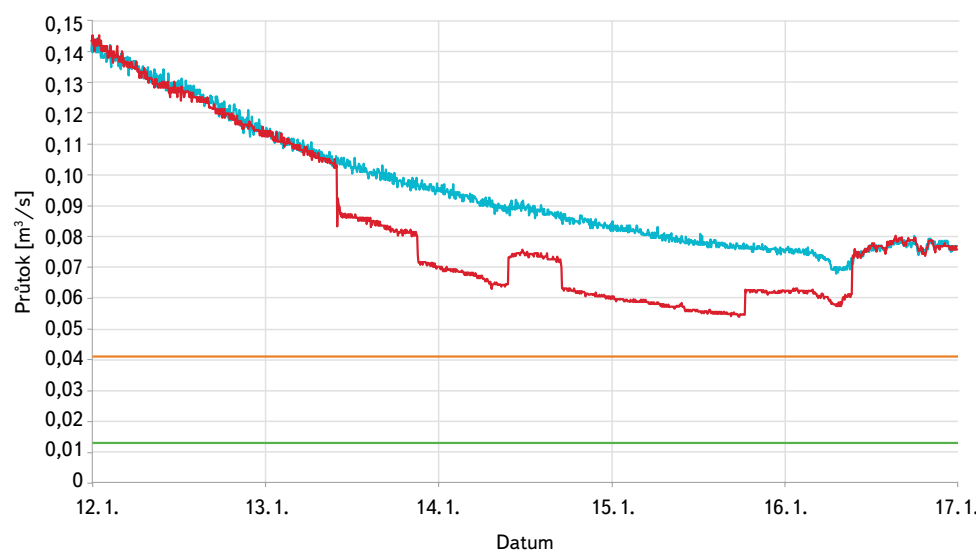

Obr. 3. Př́klad vlivu odběrư vody na průtoky středně velkého vodního toku za běžné zimy (Černohorský potok ve dnech 12. až 16. ledna 2018)

Fig. 3. An example of the effect of water abstraction on medium-sized streams during normal winters (Černohorský stream between $12^{\text {th }}-16^{\text {th }}$ January 2018)

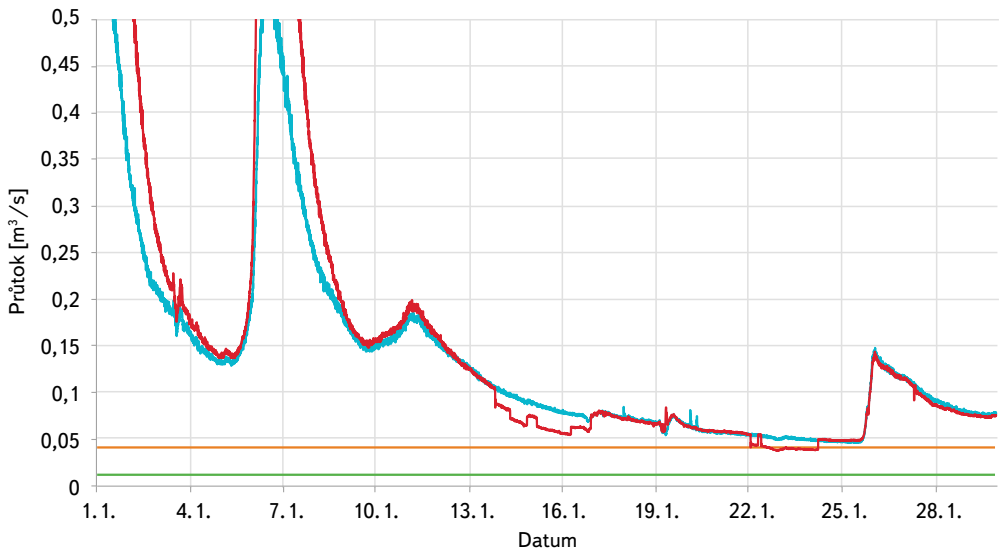

Obr. 4. Odběry vody z 12. až 16. ledna 2018 na Černohorském potoce v kontextu s ostatními lednovými průtoky

Fig. 4. Water abstraction from $12^{\text {th }}$ to $16^{\text {th }}$ January 2018 at Černohorský stream in the context of other January discharges

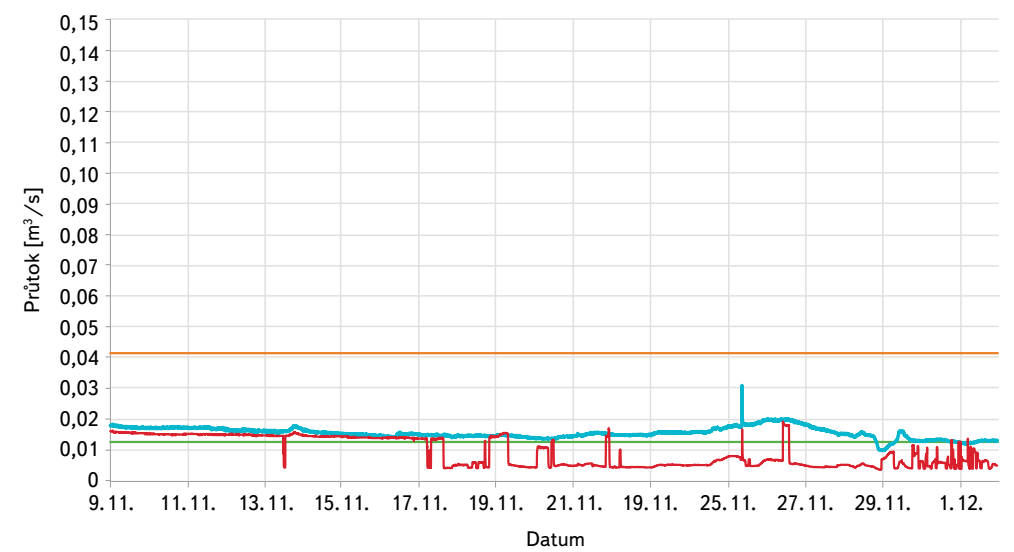

Obr. 5. Př́klad vlivu odběrů vody na průtoky středně velkého vodního toku v období nízkých průtoků - v době, kdy byl průtok pod hranicí minimálního zůstatkového průtoku pro odběry vody, tzn. období, v němž není povolen odběr vody (Černohorský potok v listopadu a začátkem prosince 2018)

Fig. 5. An example of the effect of water abstraction on medium-sized streams during small discharges - at a time when discharges were below the minimum residual flow for water abstraction, i.e. period in which water abstraction is not permitted (Černohorský stream in November and early December 2018) 


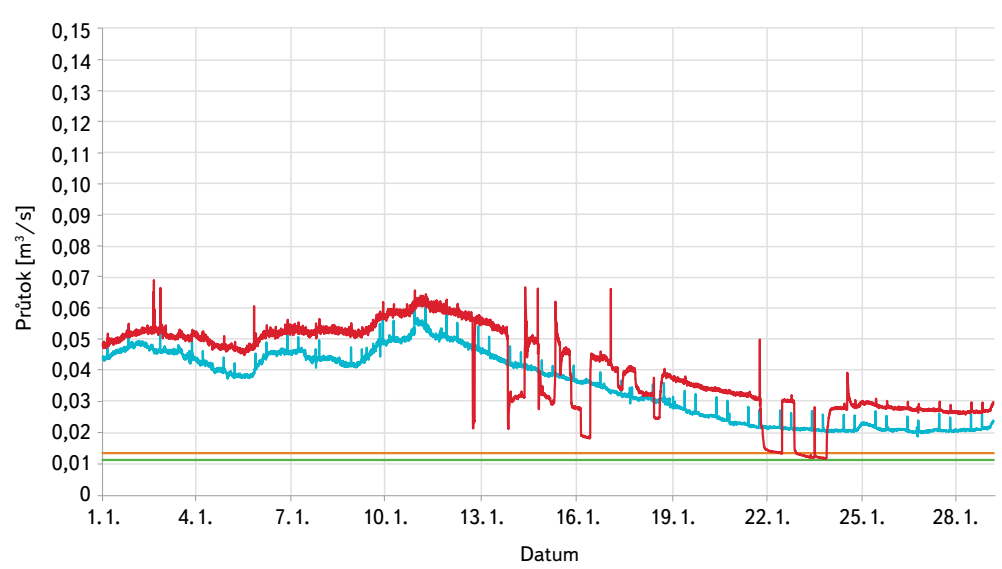

Obr. 6. Př́klad vlivu odběrů vody na prưtoky malého vodního toku za běžné zimy (Černý potok v lednu 2018)

Fig. 6. An example of the effect of water abstraction on small-sized streams during normal winters (Černý stream in January 2018)

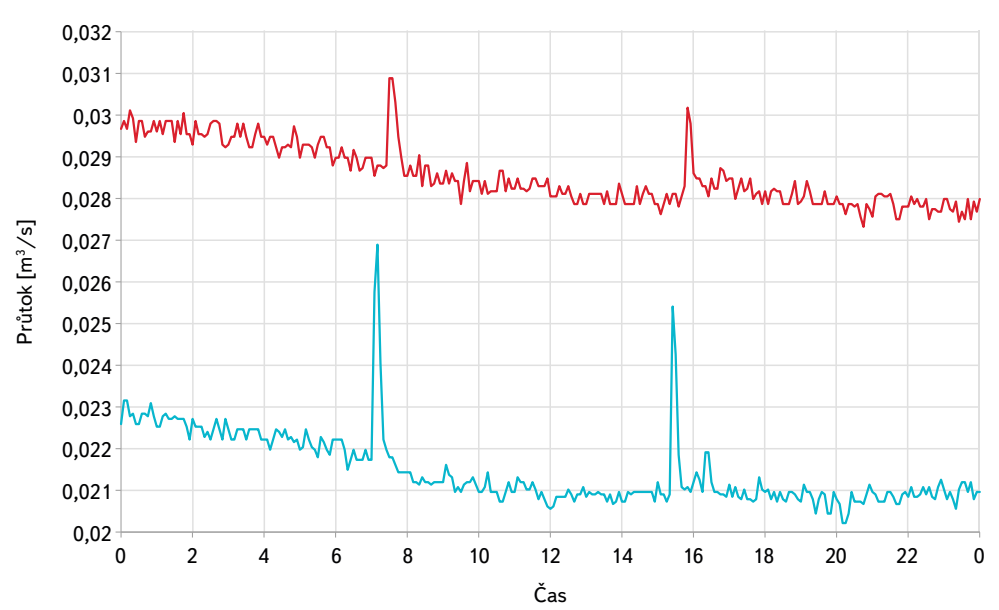

Obr. 7. Dopad antropogenní činnosti (vypouštění vod) v povodí Černého potoka; príklad vzestupu průtoků dne 19. 1. 2018 (poznámka: vzdálenost pozorovacího profilu nad a pod odběrovým místem $600 \mathrm{~m}$ )

Fig. 7. Impact of anthropogenic activity (discharge of water) in the Černý stream catchment area; example of increase of discharges on $19^{\text {th }}$ January 2018

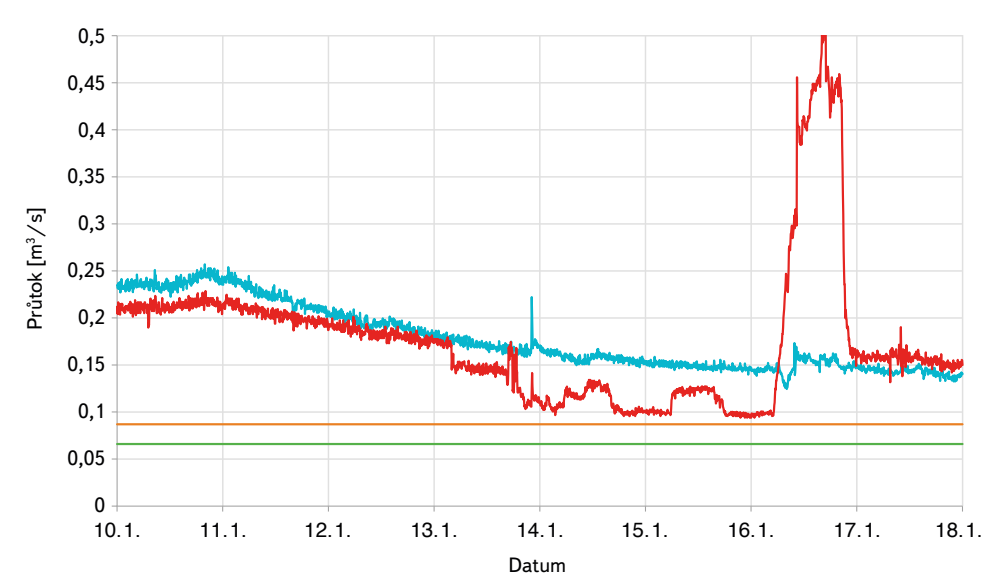

Obr. 8. Dopad antropogenní činnosti v povodí Zeleného potoka - odhrnování sněhu do vodního toku dne 16. 1. 2018, odběr vody pro technické zasněžování ve dnech 13. až 16. 1. 2018

Fig. 8. Impact of anthropogenic activity in the Zelený stream catchment area - snow removal into the stream on $16^{\text {th }}$ January 2018, water abstraction for technical snowmaking from $13^{\text {th }}$ to $16^{\text {th }}$ January 2018

Ukázky príkladů dopadu technického zasněžování na průtoky vybraných toků jsou zobrazeny na obr. 2 až 8 . Na obr. 2 je ukázán celoroční průběh průtoků na Svatopetrském potoce (potok se středně velkým průtokem, medián průtoku 0,17 m³/s). Na obr. 3 je zobrazen podrobnější pohled na jeden z typických odběrů vody pro technické zasněžování v běžné zimě (na Černohorském potoce). Na obr. 4 je dán tento odběr ( obr. 3) do souvislosti s dalšími průtoky v měsíci lednu. Je zde vidět, že přestože je odebíráno i 27 \% objemu vody, prírodní kolísání hladiny toku je významnější. Daleko významnější pro Černohorský potok byly odběry vody z listopadu 2018, které jsou zobrazeny na obr. 5. Již při letmém porovnání obr. 3 a 5 je patrné, že listopadové odběry vody (které byly realizovány $v$ době nízkých průtokư a zároveň v období, kdy byl průtok na toku menší než povolený minimální zůstatkový průtok pro odběr vody, tzn. odběry vody by neměly být podle platných vydaných rozhodnutí realizovány) měly na Černohorský potok významnější dopad, kde odběry vody v kombinaci s velmi nízkými průtoky a podnulovými teplotami vzduchu mohly vést k vymrznutí koryta toku, nebo dokonce i k jeho vyschnutí.

Jiný pohled na odběry vody pro technické zasněžování ukazuje obr. 6. Zatímco na př́kladu Černohorského potoka byl ukázán dopad na středně velké toky (kam se zařazuje většina z prezentovaných toků, medián průtoků Černohorského potoka je $0,03 \mathrm{~m}^{3} / \mathrm{s}$ ), tak Černý potok patři k těm s menším průtokem (medián $0,02 \mathrm{~m} 3 / \mathrm{s}$ ). Rozdílný u obou potoků je i roční chod průtoků. Zatímco Černý potok má průtok vyrovnanější, tak u Černohorského potoka dochází k většímu rozptylu mezi hodnotami menších a větších průtoků.). Díky menšímu průtoku na Černém potoce mají odběry vody v místě odběru na kolísání průtoku výrazně větši dopad. Negativní dopad odběrů vody je u Černého potoka kompenzován dostatečnou dotací vody z okolních zdrojů, po proudu dochází k rychlému navýšení průtoku a relativně brzké minimalizaci vlivu odběru vody.

Změna dynamiky odtoku při tání sněhu nás také zajímala - na všech profilech bylo analyzováno, jaká část odtoku pochází z prírodního sněhu a jaká část z technického sněhu. S ohledem na krátkou dobu pozorování zatím nelze 


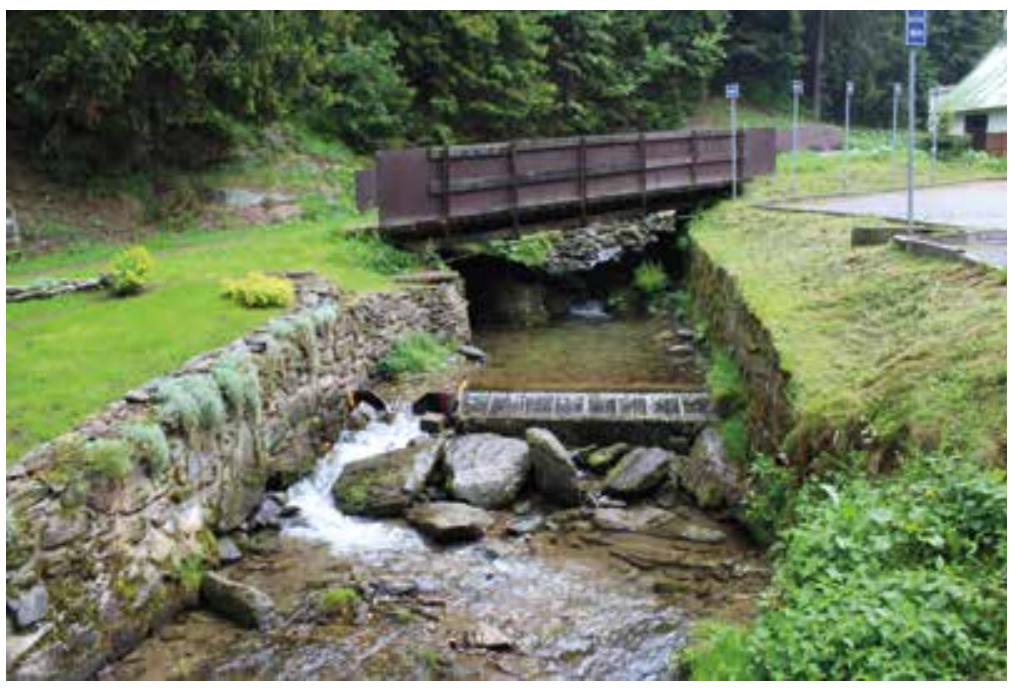

Obr. 9. Místo odběru vody pro technické zasněžování na Vlčím potoce v Peci pod Sněžkou Fig. 9. The place of water abstraction for technical snowmaking on Vlčí stream in Pec pod Sněžkou

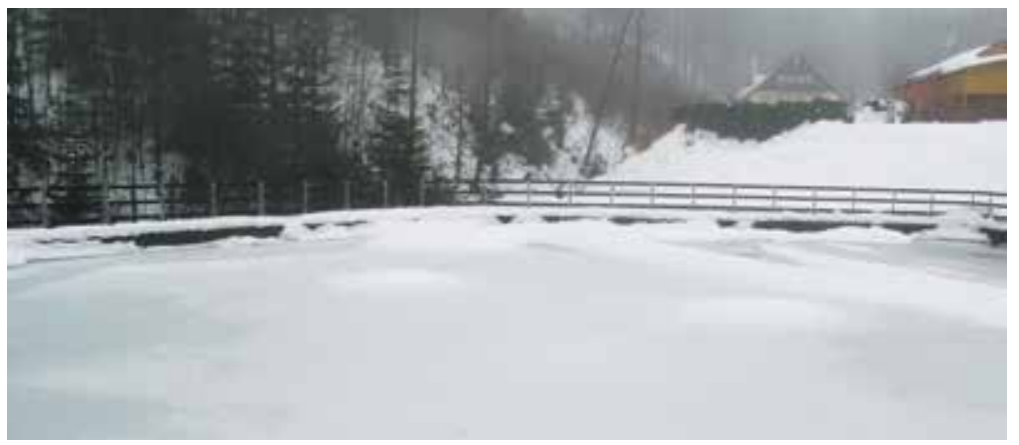

Obr. 10. Zamrzlá akumulační nádrž na odběr vody pro technické zasněžování z Janského potoka v Janských Lázních

Fig. 10. Frozen water storage reservoir for technical snowmaking from Janský stream in Janské Lázně

publikovat jednoznačné závěry, zda (o kolik a po jakou dobu) je dotace vody pocházející z tajícího technického sněhu pro nadlepšení průtoků vodních toků významná či nikoliv.

Byl sledován vliv i dalších antropogenních faktorů. V rámci měření bylo objeveno $\vee$ Rokytnici nad Jizerou na Černém potoce periodické vypouštění vod, které probíhá během hlavní turistické sezony zpravidla dvakrát denně (viz obr. 7 , dobře patrno i z obr. 6, vypouštění detekováno i na mírně zvýšených hodnotách v odebraném vzorku dne 20. 2. 2019 - viz tabulka 1 - a nepřímého kontinuálního měření konduktivity toku). V Peci pod Sněžkou bylo zaznamenáno odklízení sněhu z komunikací do vodního toku (na obr. 8 je zobrazena ukázka vlivu na průtoky Zeleného potoka). Na sledování vlivu odběrů vody pro technické zasněžování a ostatní antropogenní činnosti na pokles průtoků byla zaměřena pozornost i v rámci analýzy dopadu na soustavu jednotlivých povodí Hut'ského potoka $\checkmark$ Rokytnici nad Jizerou. Přestože byl zaznamenán na jednotlivých pozorovacích profilech těsně pod provedenými odběry vliv na pokles průtoků, dále po proudu toku byly podstatnější ostatní odběry a vypouštění a odběry vody pro technické zasněžování na průtocích nebylo možno v kombinaci s ostatními vlivy rozpoznat.

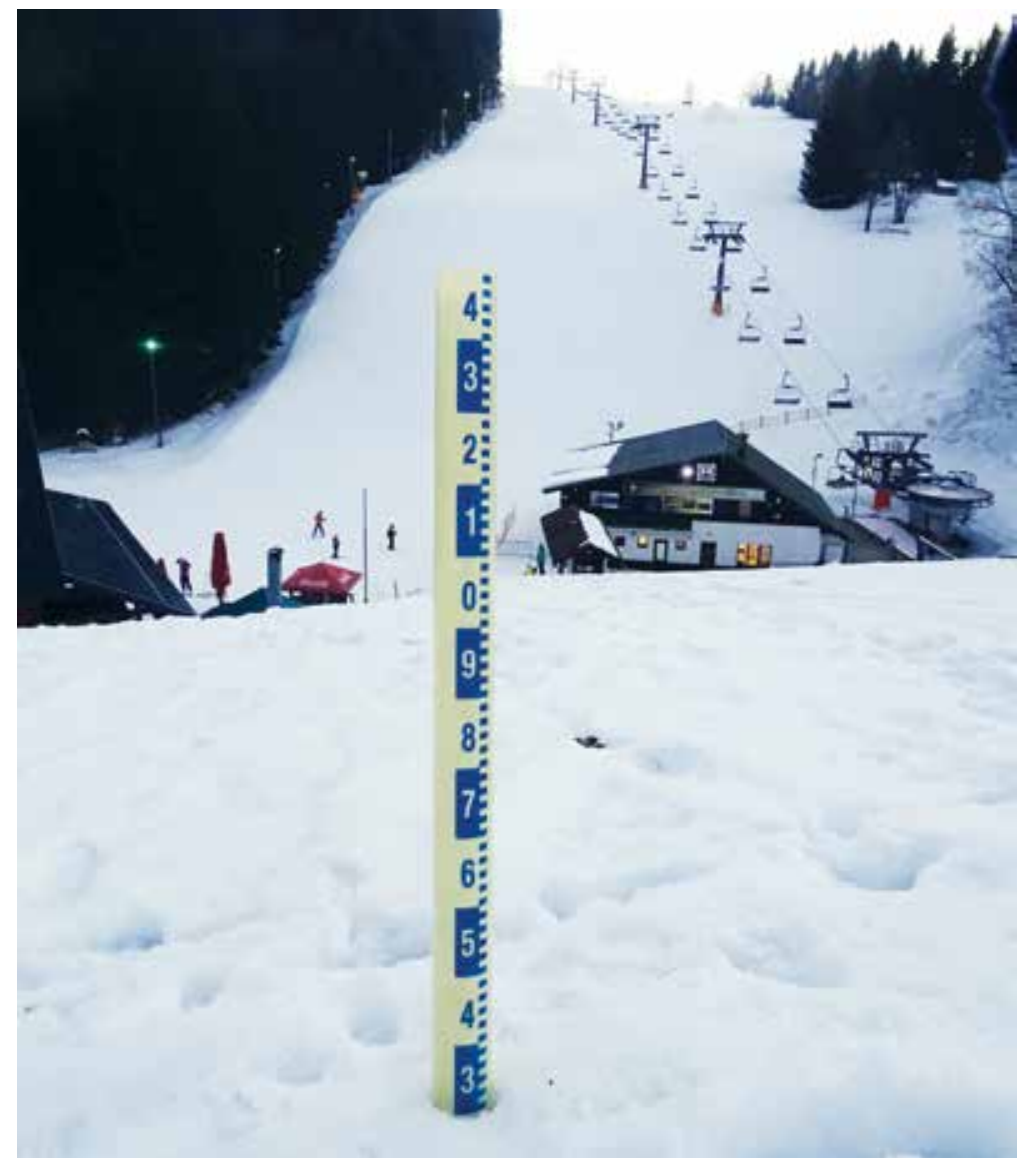

Obr. 11. Měření vodní hodnoty sněhu pomocí sněhoměru ve Vítkovicích Fig. 11. Measurement of water value of snow using snow meter in Vítkovice

\section{Posuzování dopadu technického zasněžování}

Odběry vody pro technické zasněžování mají na vodní tok obdobný vliv jako ostatní odběry vody. Je vhodné tyto odběry posuzovat stejně jako ostatní odběry. Výhodou odběrů vody pro technické zasněžování oproti ostatním odběrům je jejich realizace v zimní čtvrtině roku, kdy zpravidla bývá vyšší průtok. Existují však dvě riziková období - začátek zimní sezony, kdy často pretrvávají nízké průtoky z předchozího podzimního období s nízkým průtokem, a období, kdy dostatečně mrzne a dochází k vymrzání toků, a tudíz k poklesu průtoků v toku.

Z pohledu velikosti toku není odběr vody ze středně velkých a velkých toků (s mediánem průtoku od 0,025 m³/s) v běžné zimě při dodržení všech povolení zásadní. U menších toků je dopad odběrů vody na kolísání hladiny ve vodním toku významnější. Při dodržení všech povolených limitů by s odběry vody neměl být problém. S ohledem na neexistenci staniční sítě na malých tocích a zjednodušeným výpočtům hodnot minimálních zůstatkových průtoků (a dalších charakteristik) formou analogie stavu mezi povodími, kde existuje staniční sít, a povodím, z něhož se má realizovat odběr, může $v$ ojedinělých prípadech nastat situace, kdy odvozené hodnoty limitních hodnot průtoků mohou být $\checkmark$ některých prípadech nadhodnoceny nebo podhodnoceny. $\vee$ prípadě podhodnocení limitů může nastat problém s dodržením optimální velikosti minimálního zůstatkového průtoku. Z tohoto důvodu by bylo vhodné, aby pod každým odběrovým místem bylo instalováno certifikované zařízení na měření průtoků a na základě konkrétních dat byly upraveny povolené limity maximálního odebraného množství vody, resp. minimálního zůstatkového průtoku, aby lépe odpovídaly realitě. 
Zvláštním případem je povolený průběžný odběr vody z velmi malých toků (resp. vodotečí) s průtokem kolem jednotek I/s. Ten je nevhodný. Tyto vodoteče často nemají stálý průtok. Přestože $v$ nich $v$ zimě protéká voda, je $v$ nich složité udržet hodnotu minimálního zůstatkového průtoku. Využití vodotečí je teoreticky možné v období jarního tání či jiných extrémních srážek, kdy je vody dostatek, formou akumulace vody v retenčních nádržích.

Právě využití odtékající vody v období jarního tání a dalších období extrémních srážek je jedna z variant, jakým způsobem eliminovat případné negativní účinky odběrů vody z toků. Pokud by došlo k vybudování retenčních nádrži na akumulaci vod z tání sněhu a extrémních srážek a využití této vody pro technické zasněžování sjezdovek, neměl by být problém při jejich dostatečné kapacitě technicky zasněžit sjezdovky během celé zimní sezony a zejména na začátku sezony, kdy provozovatelé ski areálů potřebují technicky zasněžit sjezdovky před Vánoci, ale s ohledem na přetrvávající malý průtok není možno z vodních toků vodu odebírat. Někteří provozovatelé pak odebírají vodu nad rámec vydaných povolení. Zároveň by neměl být problém pokrýt i druhé kritické období, $v$ němž je během zimy $v$ toku málo vody - $v$ době, kdy hodně mrzne. Třetí potenciálně rizikovým obdobím, v němž mohou nádrže přispět ke snížení rizika zvýšených odběrů vody, je období oblevy, kdy jsou přes den vysoké teploty a během noci krátká období, v nichž mrzne, a je potřeba nárazově co nejvíce zasněžovat. $V$ prípadě, že akumulační nádrž bude postavena na vhodném místě, tak aby krajinářsky zapadla do prostředí a zároveň nenarušila ekologicky cenné prostředí, jedná se o preventivní řešení, které může eliminovat negativní odběry vody během nízkých průtoků a zároveň chránit území proti negativním dopadům jarních rozlivů. $\vee$ prípadě možných odběrů za různě velkých průtoků se nabízí i možnost lepší regulace - omezovat odběry vody z toků v období malých průtoků a naopak je směřovat do období s vyššími průtoky - např. v souvislosti s často diskutovanou problematikou poplatků za odběr vody pro zasněžování sjezdovek, kdy se vede dlouhodobá diskuse, zda výjimku pro odběry vody pro technické zasněžování sjezdovek zachovat, či nikoliv. Pokud by byl zvolen kompromis - obecné zrušení této výjimky bezplatného odběru vody pro technické zasněžování, avšak s možností prominutí tohoto poplatku $v$ prípadě že by odběry vody probíhaly pouze při nadprůměrných průtocích (a obecně byly splněny předem stanovené podmínky pro ekologicky dlouhodobě udržitelný rozvoj) a bylo měření průtoků a zařízení na odběry vody certifikováno - by na tom byly ekologicky se chovající areály stejně jako dnes. Ve vydaných povoleních by bylo potřeba definovat období nadprůměrných průtoků a ošetřit období, během něhož bude možno vodu odebírat a kdy nikoliv.

\section{HUSTOTA A VODNÍ HODNOTA SNĚHU NA TECHNICKY ZASNĚŽOVANÉ SJEZDOVCE A MIMO NI}

S ohledem na množství vody, které může odtéci ze sjezdovek, je zásadní i množství vody, které sníh obsahuje. Z tohoto důvodu je důležitá i vodní hodnota sněhu, resp. hustota sněhu. Čerstvý sníh má menší vodní hodnotu sněhu a hustotu než např. sesedlý sníh, firn nebo mokrý sníh. Zajímalo nás, jaké jsou rozdíly ve vodní hodnotě sněhu a v hustotě sněhu na sjezdovkách a mimo ně při rưzných typech počasí. Ve 12 dnech bylo provedeno celkem 211 měření v Janských Lázních, Peci pod Sněžkou, Špindlerově Mlýně, Rokytnici nad Jizerou, Pasekách nad Jizerou a Vítkovicích.

Hustota sněhu mimo sjezdovku se pohybovala mezi 0,08 a $0,28 \mathrm{~g} / \mathrm{cm}^{3}$, na sjezdovce pak mezi 0,11 a $0,43 \mathrm{~g} / \mathrm{cm}^{3}$. Vodní hodnota sněhu se pohybovala mimo sjezdovku od $159 \mathrm{~mm}$ po $557 \mathrm{~mm}$ a na sjezdovce od $188 \mathrm{~mm}$ do 742 $\mathrm{mm}$. Na sjezdovce bylo $v$ průměru mezi 1,3 až 1,9× více vody ve sněhu než mimo ně. Číslo vyjadřuje nejnižší a nejvyšší průměr z více hodnot na téže sjezdovce, resp. mimo ni. Rozpětí mezi krajními hodnotami může být značné (např. vodní hodnota sněhu v Rokytnici na sjezdovce byla v blízkém okolí od $398 \mathrm{~mm}$ do $536 \mathrm{~mm}$ ).

Rozdíl mezi množstvím vody je dán typem počasí (umrzlý sníh má vyšší vodní hodnotu než čerstvý), strukturou sněhu a zhutňováním sněhu rolbou. Vliv zhutnění rolbou je velmi dobře patrný z pozorování v terénu, kdy při odběrech sněhu sněhoměrem na sjezdovce je nejprve horní vrstva tuhá, pod rolbou zhutněnou vrstvou je postupně sníh měkčí. Pokud neprobíhá soustavné zhutňování, je rozdíl mezi vodní hodnotou na neupravované sjezdovce a mimo ni menší.

\section{ANALÝZA CHEMISMU VODY A SNĚHU}

V souvislosti s technickým zasněžováním se často diskutuje o problematice kvality vody využívané k technickému zasněžování, at’ už v souvislosti s užívanými aditivy nebo s ohledem na odběry znečištěné vody z toků díky neexistenci účinných čistíren odpadních vod u jednotlivých horských bud. K celkovému obrazu o vlivu technického zasněžování patři nejen pohled na dopad na změnu průtoků a hydrologické bilance, ale i pohled na možné znečištění menších toků (u nichž se běžně kvalita vody nesleduje) a ev. dopad takto znečištěné vody na biotu sjezdovky.

Proto bylo během zimní sezony 2018/2019 odebráno 25 vzorků, u nichž byl proveden základní chemický rozbor, kde akreditovaná laboratoř VúV TGM, v. v. i., v Praze stanovila celkový obsah dusíku a fosforu, obsah amoniakálního a dusičnanového dusíku, obsah chloridů a pH. Obsahy amoniakálního a dusičnanového dusíku pak byly výpočtem převedeny na množství amonných iontů a dusičnanů. Cílem těchto rozborů nebylo podrobně zmapovat znečištění na jednotlivých potocích a sjezdovkách a variabilitu tohoto znečištění (kde by bylo pro objektivitu potřeba provádět častý monitoring a zároveň během každého odběru vzorků odebrat současně větší množství vzorků s ohledem na proměnlivost prostředí), ale pouze orientačně zjistit, jak hodně může být voda a sníh znečištěný běžně se vyskytujícími látkami a zda je potenciálně toto znečištění významné a je potřeba ho řešit.

Na prítomnost aditiv chemické rozbory nebyly prováděny s ohledem na minimální pravděpodobnost užití těchto aditiv, vysokým nákladům na pořizení jedné chemické analýzy a s ohledem na to, že v lyžařských areálech, v nichž byla teoretická pravděpodobnost užití aditiv největší, byly prováděny analýzy podnikem Povodí Labe a v rámci projektu TITSMZP707 (Vliv technického zasněžování na biologické složky prírodního prostředí na území Krkonošského národního parku a jeho ochranného pásma).

$\checkmark$ průběhu sezony bylo během tři termínů (na začátku, uprostřed a na konci zimy) odebráno celkem 25 vzorků - 12 vzorků z potoků, 4 vzorky z nového sněhu a 9 vzorků ze sjezdovek ze všech námi sledovaných oblastí (Rokytnice nad Jizerou, Špindlerưv Mlýn, Janské Lázně, Pec pod Sněžkou). Naměřené znečištění na technicky zasněžovaných sjezdovkách bylo minimální (viz hodnoty $v$ tabulce 1). Znečištění bylo hluboko pod limity pro pitnou vodu. Jediným prípadem, kdy byly překročeny limity hodnot pro pitnou vodu, byl jeden vzorek odebraný ze sjezdovky, na níž se jel světový pohár ve sjezdovém lyžování. Obsah amonných iontů zde překračoval normu více než 16x, oproti jiným sjezdovkám byl také zvýšený obsah chloridů (avšak limity pro pitnou vodu nebyly překročeny). Zvýšené hodnoty znečištění v jednom ze dvou odebraných vzorků souvisís pravděpodobným užitím salmiaku (chlorid amonný - $\mathrm{NH}_{4} \mathrm{Cl}$ ), který se používá při závodech pro udržení optimální kvality sjezdových tratí během závodu. Analýza vzorků ze sjezdovky, na níž se jel světový pohár, byla z tohoto důvodu zvolena záměrně, protože bylo zajímavé zjistit, jak velké lokální znečištění sjezdovky mưže být, pokud se na dané sjezdovce koná vrcholová sportovní akce, na níž je s ohledem na udržení kvality sjezdových tratí během závodu a její regulérnosti nutná předzávodní úprava sjezdovky, včetně jednorázového výjimečného užití salmiaku v období, kdy je vyšší teplota vzduchu, tak, aby zůstala sjezdová trat po celou dobu tvrdá a netvořila se na ní koryta. 
Table 1. Snow and water pollution

\begin{tabular}{|c|c|c|c|c|c|c|c|c|c|c|}
\hline \multirow{2}{*}{ Vzorek } & & $\mathrm{pH}$ & $\mathrm{Cl}$ & Amonné ionty & $\mathrm{NO}_{3}$ & $\mathrm{~N}-\mathrm{NH}_{4}$ & $\mathrm{~N}-\mathrm{NO}_{3}$ & $\mathbf{N}_{\text {celk. }}$ & $\mathbf{P}_{\text {celk. }}$ & Konduktivita \\
\hline & & - & $\mathrm{mg} / \mathrm{l}$ & $\mathrm{mg} / \mathrm{I}$ & $\mathrm{mg} / \mathrm{I}$ & $\mathrm{mg} / \mathrm{I}$ & $\mathrm{mg} / \mathrm{I}$ & $\mathrm{mg} / \mathrm{I}$ & $\mathrm{mg} / \mathrm{I}$ & $\mu \mathrm{S} / \mathrm{cm}$ \\
\hline \multirow{3}{*}{$\begin{array}{l}\text { prírodní } \\
\text { sníh }\end{array}$} & od & 5,1 & $<1,00$ & $<0,050$ & $<0,500$ & $<0,039$ & $<0,113$ & $<1,00$ & $<0,025$ & 2,8 \\
\hline & do & 7,0 & $<1,00$ & 0,064 & 0,506 & 0,05 & 0,114 & $<1,00$ & $<0,025$ & 5,3 \\
\hline & sníh Sv. Petr 10. 12. 2018 & 5,1 & 2,28 & 0,151 & 0,593 & 0,117 & 0,134 & $<1,00$ & $<0,025$ & 14,4 \\
\hline \multirow{4}{*}{$\begin{array}{l}\text { sníh na } \\
\text { sjezdovce }\end{array}$} & od & 5,3 & $<1,00$ & 0,067 & $<0,500$ & 0,052 & $<0,113$ & $<1,00$ & $<0,025$ & 4,7 \\
\hline & do & 7,0 & $<1,00$ & 0,244 & 0,795 & 0,19 & 0,18 & $<1,00$ & 0,039 & 18,7 \\
\hline & $\begin{array}{l}\text { černá FIS sjezdovka } \\
\text { ve Špindlerově Mlýně } \\
\text { 13. 3. } 2019\end{array}$ & 8,2 & 19,0 & 8,18 & 0,649 & 6,35 & 0,147 & 6,54 & $<0,025$ & 93,3 \\
\hline & $\begin{array}{l}\text { sjezdovka na Hnědém } \\
\text { vrchu v Peci pod } \\
\text { Sněžkou 13. 3. } 2019\end{array}$ & 6,9 & $<1,00$ & 0,102 & 1,6 & 0,079 & 0,361 & $<1,00$ & $<0,025$ & 29,1 \\
\hline \multirow{4}{*}{ vodní toky } & od & 4,8 & $<1,00$ & $<0,050$ & 1,18 & $<0,039$ & 0,267 & $<1,00$ & $<0,025$ & 16 \\
\hline & do & 7,2 & 1,85 & $<0,050$ & 2,9 & $<0,039$ & 0,655 & $<1,00$ & 0,027 & 81 \\
\hline & Černý potok 20. 2. 2019 & 7,0 & 1,99 & 0,145 & 4,65 & 0,113 & 1,05 & 1,04 & 0,082 & 61 \\
\hline & Hut'ský potok & 7,6 & 39,0 & $<0,050$ & 5,5 & $<0,039$ & 1,24 & 1,39 & 0,049 & 155 \\
\hline \multicolumn{2}{|c|}{ Limit pro pitnou vodu } & $6,5-9,0$ & 100 & 0,5 & 50 & & & & & 1250 \\
\hline
\end{tabular}

Poznámka: V tabulce jsou zobrazeny mezní hodnoty změřených koncentrací znečištujících látek a uvedeny vzorky odchylující se od těchto hodnot. Oranžově jsou zvýrazněny hodnoty vzorků překračujíí limit pro pitnou vodu a zeleně jsou zvýrazněny hodnoty vzorků, které jsou nižší, než je hodnota mezní detekce laboratorního stanovení koncentrace dané látky.

Obdobně málo významné bylo znečištění v potocích, z nichž se odebírá voda pro technické zasněžování. Z tohoto pohledu by odběr vody z toku neměl predstavovat pro prírodní prostředí zásadnější problém. Kromě 12 komplexních vzorků analyzovaných $v$ akreditované laboratoři bylo pro vyhodnocení k dispozici ještě přes 200 měření hodnot konduktivity, která se měří průběžně za různých vodních stavů současně s měřením průtoků. Naměřené hodnoty konduktivity byly velmi nízké (mezi 16 a $81 \mu \mathrm{S} / \mathrm{cm}$ ), přičemž nejnižší nejvyrovnanější hodnoty byly na Černohorském potoce (konduktivita v rozmezí mezi 20 a 30 HS/cm) v Janských Lázních. Naopak nejvyšší konduktivita byla všeobecně na tocích v Rokytnici nad Jizerou. Vyšší znečištění (avšak výrazně pod limitem pro pitnou vodu) zde bylo $v$ Huťském potoce. Konduktivita se na horní části Hut'ského potoka pohybovala za běžných podmínek mezi 76 a 144 HS/cm, na spodní části toku pod Rokytnicí (kde se voda pro technické zasněžování neo-

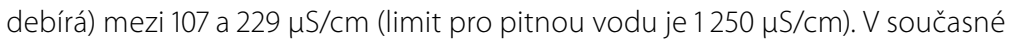
době je věnována pozornost hlavně kvalitě protékající vody v Černém potoce. Přestože odebrané vzorky z tohoto potoka prozatím svými hodnotami př́liš nevybočovaly z měření na ostatních profilech, existuje předpoklad, že na části toku tomu tak nemusí být s ohledem na vypouštění vod, které je podchyceno daty s hodnotami zvýšených průtoků a hodnotami naměřené zvýšené konduktivity $\vee$ toku. Bohužel, rozbory vzorků z toku z doby vypouštění nejsou prozatím k dispozici - nepř́mo pouze vzorek z 20. 2. 2019, který byl ale odebrán až 2 hodiny po vypouštění vody při doznívání dopadu vypouštění.

Z provedených rozborů vzorků vyplývá, že ve většině prípadů by během technického zasněžování nemělo docházet díky odběrům vody z vodních toků ke kontaminaci prírodního prostředí znečištujuícími látkami. Problematické mohou být pravděpodobně pouze jednotky prípadů, kdy probíhá nepovolené vypouštění odpadních vod, popř. je nedostatečně účinná lokální čistírna odpadních vod.

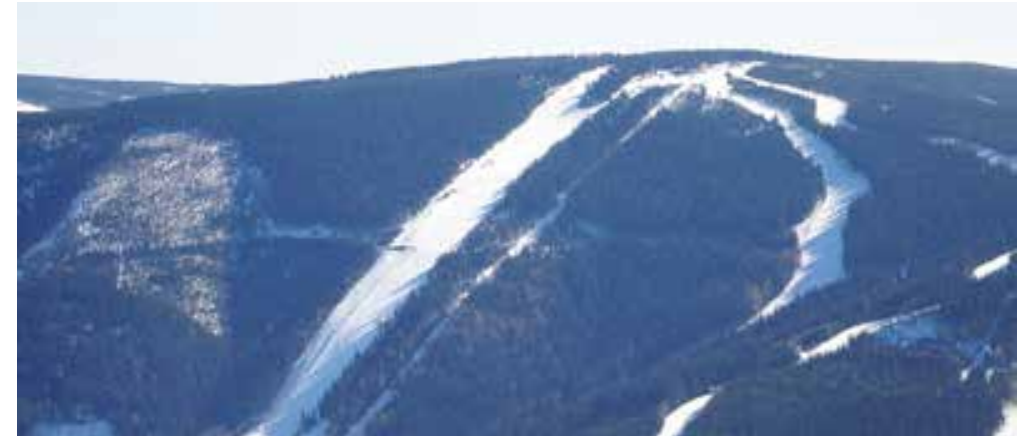

Obr. 12. Sjezdové tratě ve Svatém Petru ve Špindlerově Mlýně; v levé části snímku černá FIS sjezdovka, na níž se jel světový pohár ve sjezdovém lyžování a kde byly naměřeny zvýšené koncentrace amonných iontů

Fig. 12. Ski slopes in Svatý Petr in Špindlerův Mlýn

\section{ZÁVĚR}

Odběry vody pro technické zasněžování nepředstavují při běžné zimě na středně velkých a velkých tocích při dodržení maximálního povoleného množství odebrané vody pro technické zasněžování zásadní problém. Menší toky jsou s ohledem na možnost výraznějšího kolísání hladiny zranitelnější. V zimní sezoně existuji dvě kritická období (začátek zimy a období mrznutí), v nichž se mohou potenciálně častěji vyskytnout nízké průtoky, a s ohledem na jejich výskyt není žádoucí, aby probíhaly odběry vody. Pro preklenutí těchto období je ideální využít akumulační nádrže naplněné vodou odebranou v období se zvýšenými průtoky. 
$4 x-5=$

$\sin \sin ^{2}$

M.

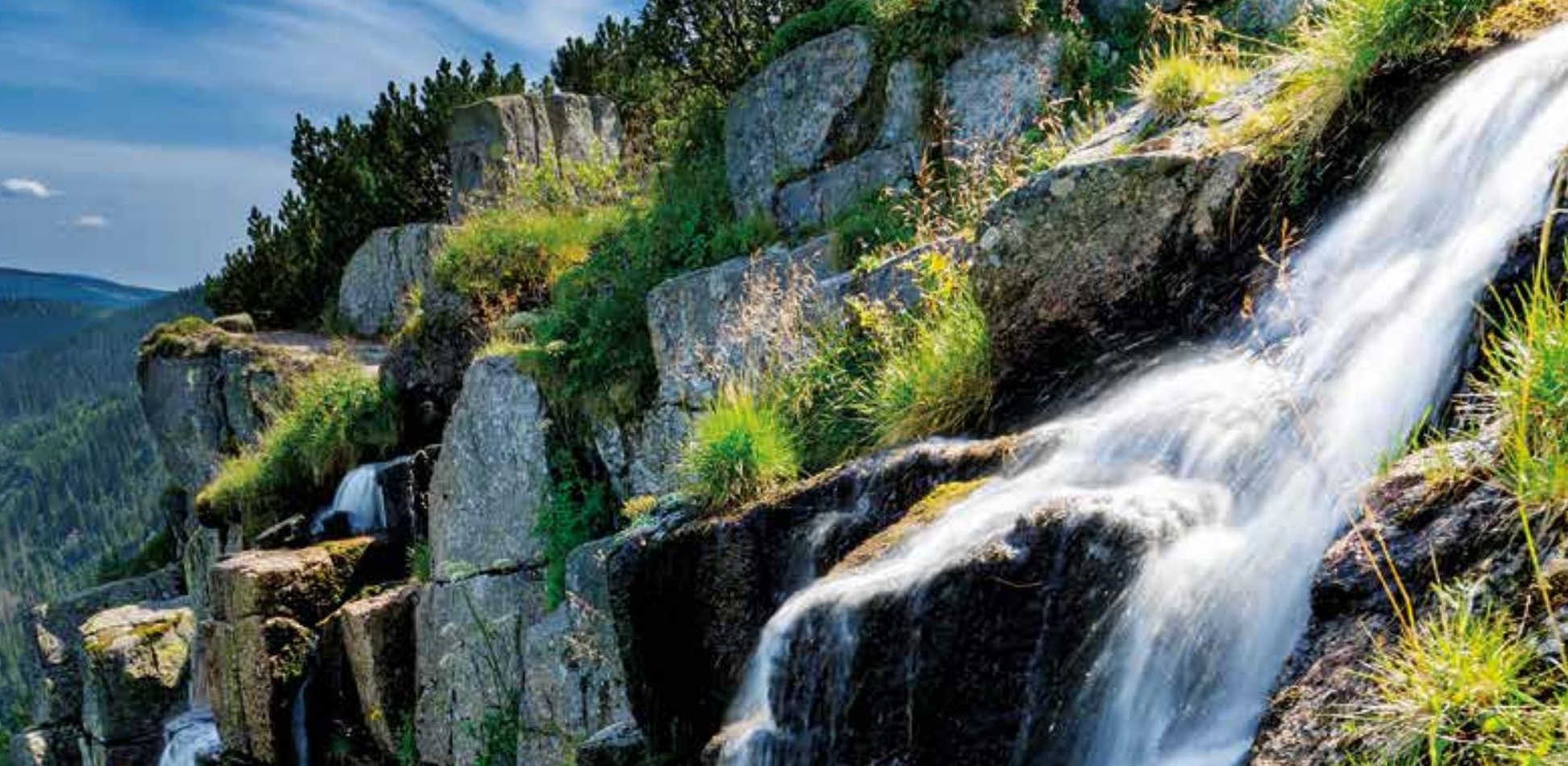
nit) $-2+3=$ , 18

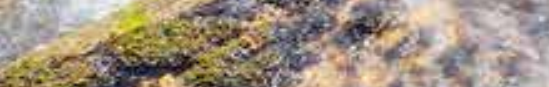
(t): 5. torter

x

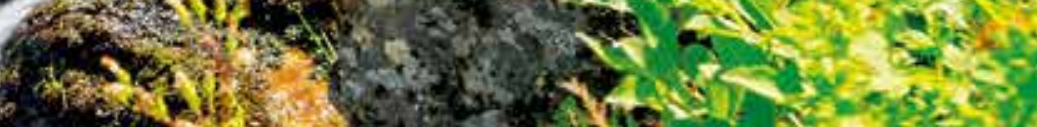
1.

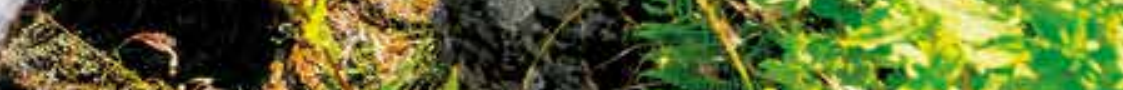

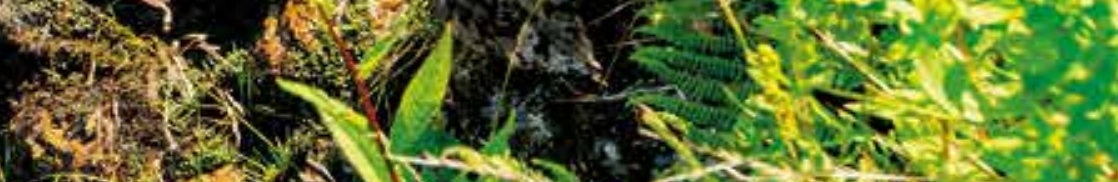

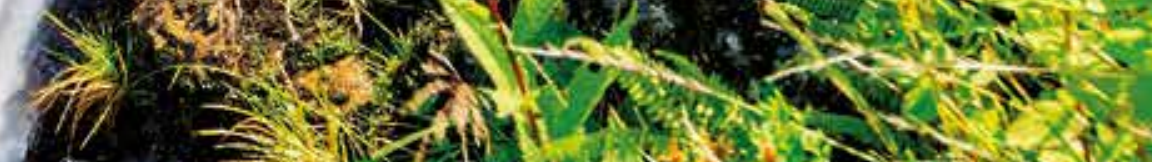

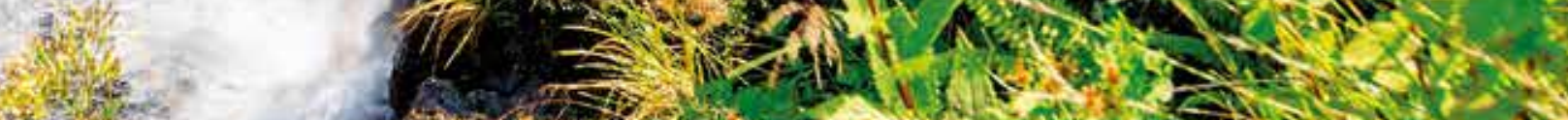

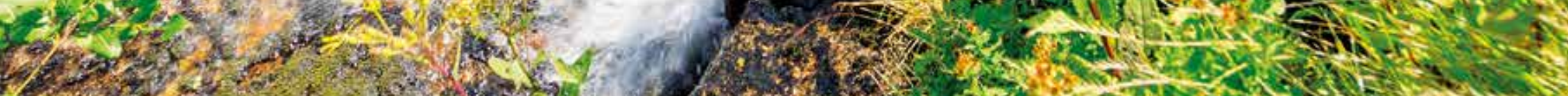

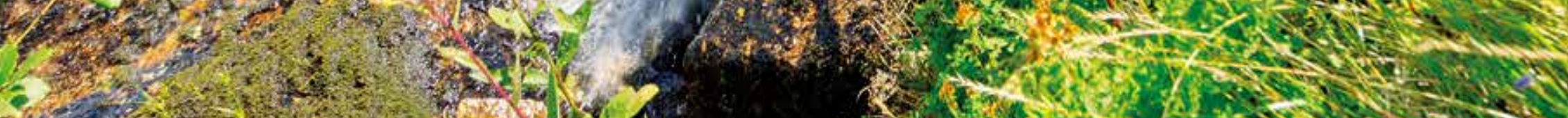

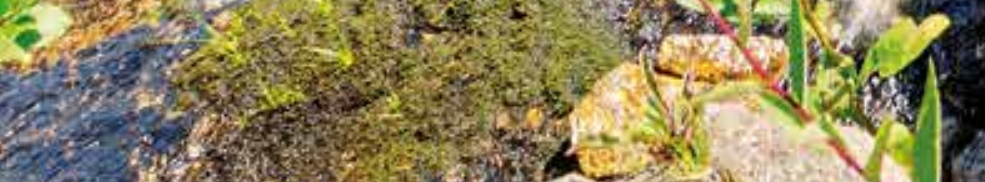

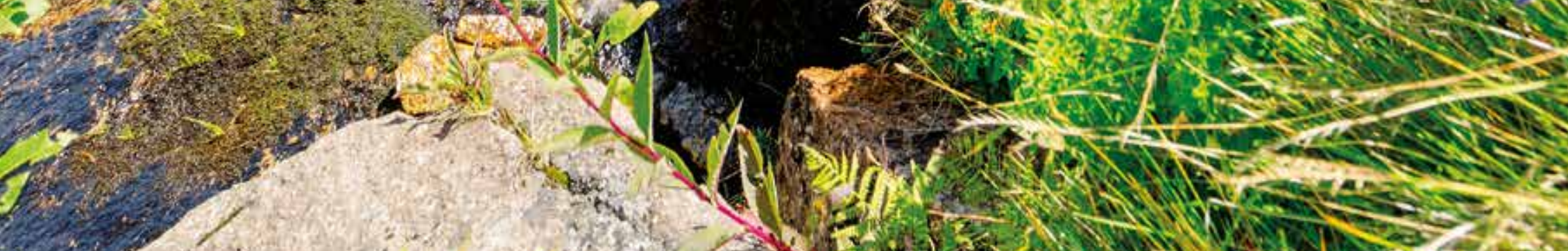

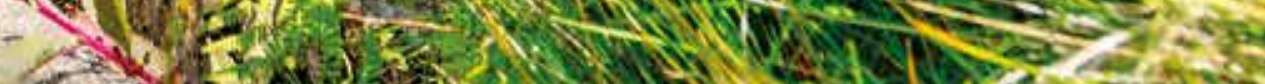
WhA 
Odběry vody pro technické zasněžování mají na vodní tok obdobný vliv jako ostatní odběry vody. Je vhodné tyto odběry posuzovat stejně jako ostatní odběry a brát v potaz i ostatní antropogenními vlivy (vypouštění vod, shrnování sněhu do toku apod.). V kontextu ostatních odběrů a antropogenních vlivů maji odběry vody pro technické zasněžování za běžných podmínek spiše menší vliv než ostatní antropogenní činnost. Vlivy odběrů vody pro technické zasněžování na toky jsou tak přeceňovány.

Z hlediska znečištění vody v tocích, z nichž se odebírá voda pro technické zasněžování, i ze sněhu nebyly za běžných podmínek naměřeny žádné znepokojivé údaje. Jediné vyšší koncentrace znečištujících látek se vyskytly nárazově ve vzorku ze sjezdovky, na níž se jel světový pohár ve sjezdovém lyžování. Z hlediska porovnávání hustoty sněhu na sjezdovce a mimo ni má sníh na sjezdovce približně $1,5 \times$ větší hustotu než mimo ni.

\section{Poděkování}

Př́spěvek vznikl v rámci výzkumného projektu Technologické agentury ČR a označením TH02030080 a názvem Podpora dlouhodobého plánovánív oblasti vodního hospodářství na území Krkonošského národního parku s dưrazem na řešení problematiky vlivu technického zasněžování na pokles průtoků s cílem zvýšit dlouhodobou efektivitu ochrany prírody a krajiny.

Poděkovánípatří i ostatním kolegům z Odboru hydrologie, hydrauliky a hydrogeologie VÚV TGM, v. v. i., kteři se spolupodíleli na výstavbě staniční sítě a měřeních.

\section{Literatura}

[1] TREML, P., HANEL, M., KAŠPÁREK, L., NOVICKÝ, O. a BŘEZINA, S. Vliv odběrů vody pro technické zasněžování na odtokovou výšku hlavních toků v Krkonoších. Opera Corcontica, 2012, roč. 49, s. 73-87.

[2] VANHAM, D., TOFFOL, S., FLEISCHHACKER, E., and RAUCH, W. Water demand for snowmaking under climate change conditions in an al pine environment. In: BORSDORF, A., STÖTTER, J., VEULLIET, E. (eds.) Managing Alpine Future II. Proceedings of the Innsbruck Conference of Austrian Academy of Science, 2011, p. 228-234.

[3] ABEGG, B. Natürliche und technische Schneesicherheit in einer wärmeren Zukunft. In: Alpine Schnee- und Wasserressourcen gestern, heute, morgen, 2012, p. 29-35.

[4] STEIGER, R. and MAYER, M. Snowmaking and Climate Change. Mountain Research and Development, 2008, vol. 28, No. 3, p. 292-298

[5] STEIGER, R. The impact of climate change on ski season length and snowmaking requirements in Tyrol, Austria, 2010, vol. 43, No. 3, p. 251-262.

[6] ZAPPA, M., BERNHARD, L., FUNDEL, F., \& JÖRG-HESS, S. Vorhersage und Szenarien von Schneeund Wasserressourcen im Alpenraum. In: Alpine Schnee- und Wasserressourcen gestern, heute, morgen, 2012, p. 19-27.

[7] KPMG. Horská střediska v ČR - identifikace přínosů pro regionální rozvoj a veřejné rozpočty, 2014, 173 s. [8] PÜTZ, M. GALLATI, D., and KYTZIA, S. Winter Tourism, Climate Change, and Snowmaking in the Swiss Alps: Tourists' Attitudes and Regional Economic Impacts. Mountain Research and Development, 2011, vol. 31, No. 4, p. 357-362.

[9] FLOUSEK, J. Vliv lyžování na horskou prírodu: shrnutí současných poznatků a stav v Krkonoších. Opera Corcontica, 2016, roč. 53, s. 15-60.

[10] FLOUSEK, J. a HARČARIK, J. Sjezdové lyžování a ochrana přírody. Ochrana prírody, 2009, roč. 64, č. 6, s. 8-10.

[11] ŠTURSA, J. Ekologické aspekty sjezdového lyžování v Krkonoších. Opera Corcontica, 2007, roč. 44, Č. 2, s. 603-616.

[12] KOCKOVÁ, J. Srovnání vegetace sjezdových tratí s umělým a prírodním sněhem v CHKO Bílé Karpaty a v CHKO Beskydy. Bakalářská práce, Jihočeská univerzita v Českých Budějovicích, 2008, 29 s.

[13] BUJALSKÝ, L., BŘEEZINA, S., MATĚJIČEK, L. a FROUZ, J. Světelné znečištění způsobené umělým osvětlením sjezdovek v Krkonošském národním parku. Opera Corcontica, 2014, roč. 51, s. 109-124.

[14] TEICH, M., LARDELLI, C., BEBI, P., GALLATI, D., KYTZIA, S., POHL, M., PÜTZ, M., and RIXEN, C. Klimawandel und Wintertourismus: Ökonomische und ökologische Auswirkungen von technischer Beschneiung. Birmensdorf, Eidg. Forschungsanstalt für Wald, Schnee und Landschaft WSL, 2007.

[15] CARAVELLO, G., CRESCINI, E., TAROCCO, S., and PALMERI, F. Environmental modifications induced by the practice of "Artificial snow-making" in the Obereggen/Val D'Ega Area (Italy). Journal of Mediterranean Ecology, 2006, vol. 7, p. 31-39.
[16] RIXEN CH TEICH, M LARDELLI C GALLATI, D, POHL, M PÜTZ, M, and BEBL, P. Winter Tourism and Climate Change in the Alps: An Assessment of Resource Consumption, Snow Reliability, and Future Snomaking Potential. Mountain Research and Development, 2011, vol. 31, No. 3, p. 229-236.

[17] DANKO, M., HOLKO, L., KRAJČÍ, P. a HLAVČO, J. Meranie a modelovanie snehovej pokrývky $\checkmark$ horskom mikropovodí. In: BRYCH, K. a TESAŘ, M. (eds.) Hydrologie malého povodí. Ústav pro hydrodynamiku AV ČR, 2017, s. 10-12. ISBN 978-80-87117-15-6.

[18] JONAS, T. Monitoring von Schneewasserressourcen in der Schweiz. In: GURZELER, S. (ed.) Alpine Schnee- und Wasserressourcen gestern, heute, morgen. Eidgenössische Forschungsanstalt WSL, 2012, p. 7-12.

[19] LEHNING, M., GRÜNEWALD, T.,MARTY, CH.,MOTT, R., and STÄHLI, M. Kleinräumige Schneeverteilung und Einfluss der Topographie. In: GURZELER, S. (ed.) Alpine Schnee-und Wasserressourcen gestern, heute, morgen. Eidgenössische Forschungsanstalt WSL, 2012, p. 14-18.

[20] LEHNING, M., VÖLKSCH, I., GUSTAFSSON, D., NGUYEN, T.A., STÄHLI, M., and ZAPPA, M. ALPINE3D a detailed model of mountain surface processes and its application to snow hydrology. Hydrol. Process., 2006, vol. 20, p. 2111-2128.

[21] LEHNING, M. BARTELT, P, BROWN, RLL and FIERZ, C. A physical SNOWPACK model for the Swiss avalanche warning, Part III: meteorological forcing, thin layer formation and evaluation. Cold Regions Science and Technology, 2002, vol. 35, p. 169-184.

[22] ESSERY, R.S., MORIN, Y., LEJEUNE, Y., and MÉNARD, C. A comparison of 1701 snow models using observations from an alpine site. Adv. Water Resour, 2013, vol. 55, p. 131-148.

[23] HAMBERGER, S. and DOERING, A. Der gekaufte Winter - Eine Bilanz der künstlichen Beschneiung in den Alpen. Gesellschaft für ökologische Forschung und BUND Naturschutz in Bayern BN, 2015, 123 p.

[24] HAHN, F. Künstliche Beschneiung im Alpenraum - Ein Hintergrundbericht. CIPRA International, $2004,18 p$

[25] Sníh v ČR a okolí dne 15. 1. 2019 v 7:00 SEČ. [cit. 15. 1. 2019]. Dostupné z: http://portal.chmi.cz/ aktualni-situace/aktualni-stav-pocasi/ceska-republika/snehove-zpravodajstvi/mereni-chmu/ snih-v-CR

\section{Autor}

Mgr. Pavel Treml

凶pavel.treml@vuv.cz

Výzkumný ústav vodohospodářský T. G. Masaryka, v. v. i.

Příspěvek prošel lektorským řízením.

\section{IMPACT OF SNOWMAKING ON STREAMS IN THE GIANT MOUNTAINS}

\section{TREML, P.}

TGM Water Research Institute, p.r.i.

Keywords: snowmaking - slope - discharge - flow level minimum residual flow - snow - water pollution - nature protection

The paper analyses effects of snowmaking on stream flows in the Giant Mountains, detailed analysis of runoff conditions and differences in amount of water contained in technical and natural snow. Attention is paid to possible interaction between water abstraction and water pollution. 